総説

\title{
特集：自己免疫疾患の病態形成に関わる細胞·分子と臨床応用
}

制御性 T 細胞と自己免疫疾患

田中＼cjkstart聡，坂口志文

\section{Regulatory $T$ cell and autoimmune diseases}

Satoshi TANAKA, Shimon SAKAGUCHI

Department of Experimental Pathology, Institute for Frontier Medical Sciences, Kyoto University

(Received September 16, 2005)

\begin{abstract}
summary
$\mathrm{CD} 25+\mathrm{CD} 4+$ regulatory $\mathrm{T}$ cells are naturally anergic and suppressive. They differentiate through thymus as professional regulator to control immunological self-tolerance in the periphery. When they are depleted from normal animals, various organ-specific autoimmune diseases spontaneously develop, and reconstitution of regulatory $\mathrm{T}$ cells prevents the diseases. Transcriptional factor FoxP3 is the master gene for differentiation and function of regulatory $\mathrm{T}$ cells. Mutation of FoxP3 gene causes development of autoimmune disease in both human and mouse. There are accumulating reports that regulatory $\mathrm{T}$ cells are abnormal in their number or function in several animal models and also patients with autoimmune diseases. These findings indicate that regulatory $\mathrm{T}$ cells are involved in the pathogenesis of many autoimmune diseases. Regulatory $\mathrm{T}$ cells can also be employed for the treatment of autoimmune diseases. Further studies of regulatory $\mathrm{T}$ cells, especially the detection of their specific markers and the development of the method to propagate them in an antigen-specific manner, will facilitate their clinical application.
\end{abstract}

Key words $-\mathrm{CD} 25+\mathrm{CD} 4+$ regulatory $\mathrm{T}$ cell, Autoimmune disease, Peripheral tolerance, Treatment

抄 録

内在性 $\mathrm{CD} 25+\mathrm{CD} 4+$ 制御性 $\mathrm{T}$ 細胞は，胸腺で産生され，試験管内での抗原刺激に対して，自らは低反応であ り, 他の $\mathrm{T}$ 細胞の増殖を抑制する。この細胞集団を生体より除去すると, 各種の臓器特異的な自己免疫疾患が自 然発症する。その際, 制御性 $\mathrm{T}$ 細胞を移入すれば, 自己免疫病の発症が阻止される。すなわち, 制御性 $\mathrm{T}$ 細胞 は，未梢での免疫自己寛容の維持に重要な働きをしている. CD25+CD4+ 制御性 T 細胞の発生及び機能発現のマ スター制御分子は，転写因子FoxP3 であり，FoxP3 の異常は，ヒトの自己免疫病の原因となる．また，自己免疫 マウスモデルや自己免疫疾患患者において, 制御性 $\mathrm{T}$ 細胞に量的もしくは機能的異常を認める. 自己免疫マウス モデルを用いた実験では，制御性 $\mathrm{T}$ 細胞の移入により，発症後の自己免疫疾患を治療することが可能である. 制 御性 $\mathrm{T}$ 細胞をヒトの自己免疫疾患の治療に応用するには, 制御性 $\mathrm{T}$ 細胞と活性化 $\mathrm{CD} 25+\mathrm{T}$ 細胞を区別できる細 胞表面マーカーの検索, 抗原特異的な制御性 $\mathrm{T}$ 細胞の増殖法の開発などが重要課題である.

\section{CD25＋CD4＋制御性 T 細胞とは}

免疫自己寛容，すなわち，自己と非自己を識別 し，自己抗原とは反応せず，非自己抗原のみに反応 するため，高等生物は種々の機序を進化させてき た. 代表的なのは, 胸腺での自己反応性 $\mathrm{T}$ 細胞レ パトアの除去であるが，これ単独では，免疫自己寛 容は不完全である．胸腺は自己反応性リンパ球を抑 制するような細胞集団を同時に産生することで，そ

京都大学再生医科学研究所生体機能調節学
れを補つている. CD25+CD4+ 制御性 T 細胞（以 下，制御性 $\mathrm{T}$ 細胞）は，抑制機能をもつように特 化した細胞として胸腺で産生され，末梢において， 自己反応性 $\mathrm{T}$ 細胞レパトアを抑制することで, 免 疫自己寛容の維持に重要な役割を果たしている1). マウスやヒトで，未梢 CD4＋T 細胞の 5-10\%を制 御性 $\mathrm{T}$ 細胞が占めている. 制御性 $\mathrm{T}$ 細胞は, 試験 管内での TCR 刺激に対して自らの増殖活性は低い が, 他の $\mathrm{T}$ 細胞の増殖反応を細胞接着依存性に抑 制する。制御性 $\mathrm{T}$ 細胞がどのような分子的機序に より, 他の $\mathrm{T}$ 細胞増殖を抑制しているかは, 現在 
のところ不明である. 制御性 $\mathrm{T}$ 細胞の胸腺での分 化および機能発現には，マスター遺伝子として，転 写因子 FoxP3 が関与している2)。また, 制御性 T 細胞が胸腺においてどのように細胞選択を受けてい るかは明らかでないが，制御性 $\mathrm{T}$ 細胞は， CD25$\mathrm{CD} 4+\mathrm{T}$ 細胞に比べて，自己抗原に高い親和性を もつ $\mathrm{T}$ 細胞受容体を有している3)。このことは，自 己抗原により制御性 $\mathrm{T}$ 細胞が容易に活性化を受 け，自己反応を抑制するのに有利である。制御性 T 細胞は，IL-2 受容体である CD25 を細胞表面に発 現している以外にも，CTLA-4 や GITR を CD25$\mathrm{CD} 4+\mathrm{T}$ 細胞に比べて高発現しており, 前述の FoxP3 の細胞内での発現は制御性 $\mathrm{T}$ 細胞特異的で ある。また，制御性 $\mathrm{T}$ 細胞の末梢での生存維持に
は, CD25-CD4+ T 細胞に比べて，インターロイ キン-2への依存度が高(4)このように, 制御性 T 細胞は，他の $\mathrm{T}$ 細胞と比べて，機能的にも発生的 にも特異な $\mathrm{T}$ 細胞亜群である.

\section{2. 制御性 T 細胞の異常と自己免疫}

制御性 $\mathrm{T}$ 細胞が，末梢での免疫自己寛容の維持 に重要であることは，この細胞集団を生体から除去 すると, 種々の臟器特異的自己免疫疾患を発症する ことから明らかである．例えば， BALB/c マウスの 末梢 $\mathrm{CD} 4+\mathrm{T}$ 細胞から $\mathrm{CD} 25+$ 細胞を除去して, 同系のヌードマウスに移入すると, 自己免疫性胃 炎, 卵巣炎, 甲状腺炎が起きる5)。 あるいは，新生 仔胸腺摘出術や抗 IL-2 抗体投与により，正常マウ

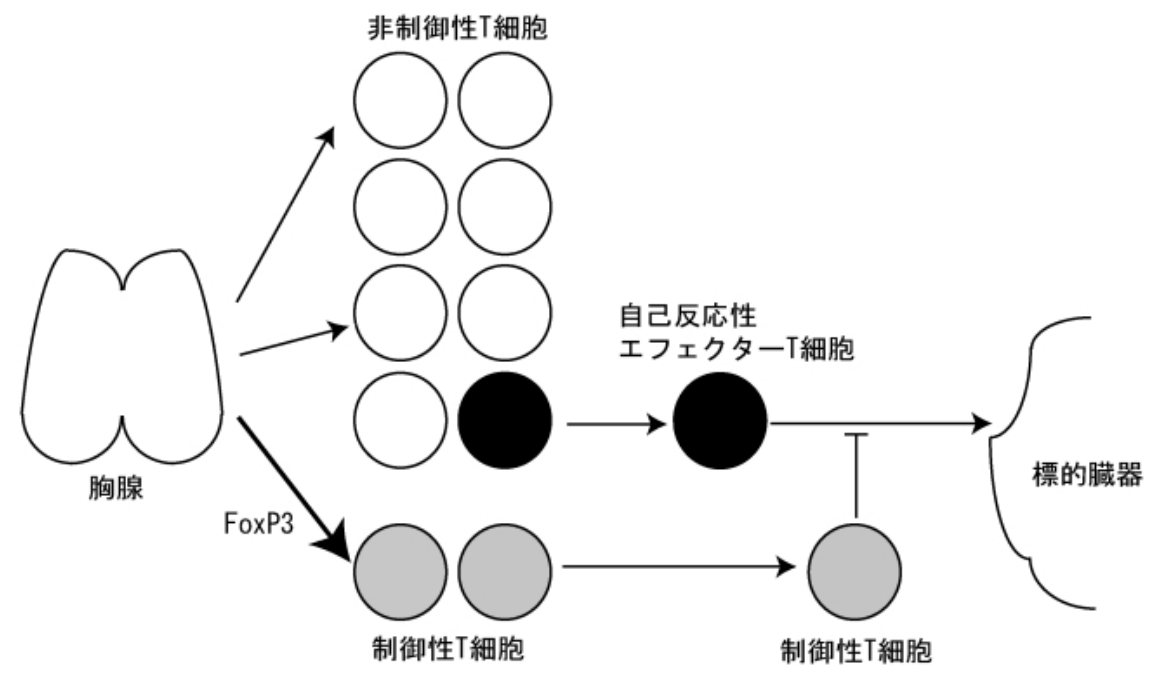

図 1 制御性 $\mathrm{T}$ 細胞の分化と機能

表 1 制御性 $\mathrm{T}$ 細胞特異的マーカー

\begin{tabular}{|c|c|c|c|}
\hline & $\bar{r}$ & ウ ス & \\
\hline & $\begin{array}{l}\text { 制御性 } \\
\mathrm{T} \text { 細胞 }\end{array}$ & $\begin{array}{c}\text { ナイーブ } \\
\mathrm{CD} 4+\mathrm{T} \text { 細胞 }\end{array}$ & $\begin{array}{c}\text { 活性化 } \\
\mathrm{CD} 4+\mathrm{T} \text { 細胞 }\end{array}$ \\
\hline $\mathrm{CD} 25$ & + & - & + \\
\hline CD45RB & Low & High & Low \\
\hline CD69 & - & - & + \\
\hline CD103 & + & $+/-$ & + \\
\hline CD122 & + & - & + \\
\hline CLTA-4 & + & - & + \\
\hline GITR & High & Low & High \\
\hline FoxP3 & + & - & - \\
\hline
\end{tabular}

\begin{tabular}{|c|c|c|c|}
\hline & \multicolumn{2}{|c|}{ 匕 } & \\
\hline & $\begin{array}{l}\text { 制御性 } \\
\mathrm{T} \text { 細胞 }\end{array}$ & $\begin{array}{c}\text { ナイーブ } \\
\mathrm{CD} 4+\mathrm{T} \text { 細胞 }\end{array}$ & $\begin{array}{c}\text { 活性化 } \\
\mathrm{CD} 4+\mathrm{T} \text { 細胞 }\end{array}$ \\
\hline $\mathrm{CD} 25$ & High & Low & High \\
\hline CD45RA & Low & High & Low-Moderate \\
\hline $\mathrm{CD} 45 \mathrm{RO}$ & High & Low & Moderate \\
\hline CD69 & - & - & + \\
\hline CD122 & High & Low & High \\
\hline CLTA-4 & High & Low & High \\
\hline GITR & High & Low & High \\
\hline HLA-DR & High & Low & High-Moderate \\
\hline FoxP3 & + & - & - \\
\hline
\end{tabular}




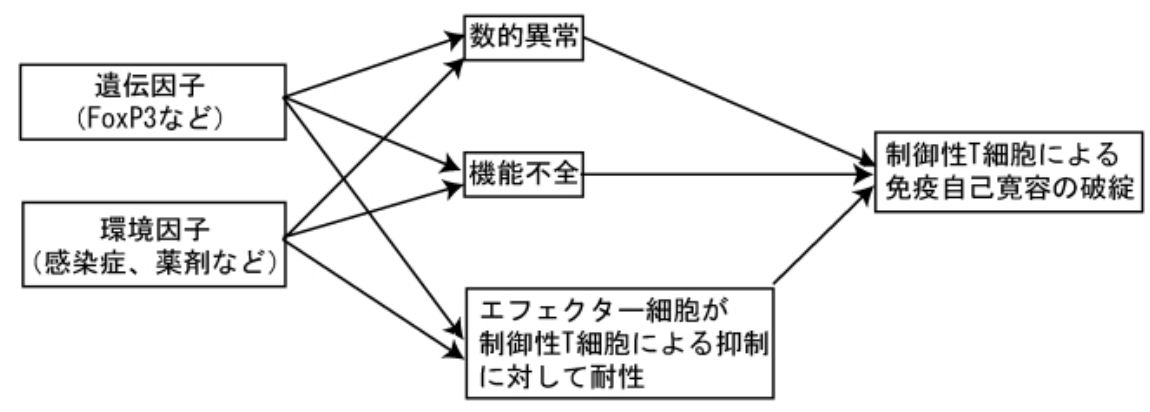

図 2 制御性 $\mathrm{T}$ 細胞の異常の機序

スから，制御性 $\mathrm{T}$ 細胞を選択的に除去しても，同 様の自己免疫疾患を誘導できる ${ }^{4,6)}$. また, 自己免 疫疾患を誘導すると同時に，制御性 $\mathrm{T}$ 細胞を移入 すると，自己免疫疾患の発症を阻止できる，例えば， $\mathrm{BALB} / \mathrm{c}$ マウスの $\mathrm{CD} 25-\mathrm{CD} 4+\mathrm{T}$ 細胞を同系 $\mathrm{T}$ 細 胞欠損マウスに移入する際, BALB/c マウス由来の 制御性 $\mathrm{T}$ 細胞を共移入すると, 自己免疫性胃炎や 卵巣炎を発症しない5)。新生仔胸腺摘出術後, 数日 のうちに，制御性 $\mathrm{T}$ 細胞を移入した場合も，自己 免疫疾患発症を抑制する。一方, FoxP3 遺伝子変 異のために FoxP3 蛋白を欠損している Scurfy マウ スは, 制御性 $\mathrm{T}$ 細胞が分化できず, 非制御性 $\mathrm{CD} 4+\mathrm{T}$ 細胞が過剰に増殖し，さまざまな臟器に リンパ球浸潤を認め，自己免疫疾患を生じる7)。同 様にヒトの FoxP3 遺伝子の変異は, 糖尿病, 腸炎 など多種の自己免疫疾患を合併した Immune dysregulation, polyendocrinopathy, enteropathy, Xlinked syndrome (IPEX) の原因となる ${ }^{8)}$. すなわ ち，制御性 $\mathrm{T}$ 細胞の異常は，ヒトでも自己免疫病 の原因となる.

\section{3. 制御性 $\mathbf{T}$ 細胞と自己免疫モデルマウス}

制御性 $\mathrm{T}$ 細胞は，マウスの自己免疫疾患モデル においても，発症に関与している。 I 型糖尿病（自 己免疫性糖尿病）を自然発症する，NOD マウスで は， $\mathrm{CD} 4+$ 細胞中の制御性 $\mathrm{T}$ 細胞の頻度が他のマ ウスに比べて少ない99. また，このマウス由来の制 御性 $\mathrm{T}$ 細胞は, 加齢とともに生体内及び試験管内 での抑制機能も低下する10)。さらには，このマウス では，若年期に制御性 $\mathrm{T}$ 細胞を移入することで, 糖尿病の発症を予防できる。NOD マウスの糖尿病 発症の原因には, 主要組織適合性複合体 (MHC) など多くの遺伝子が発症に関与していることが知ら れている。また，このマウスでは，胸腺での $\mathrm{T}$ 細 胞選択など，他の免疫自己寛容維持機構にも異常を
認める。制御性 $\mathrm{T}$ 細胞の異常が，ぞの程度に糖尿 病発症を説明できるか, 更なる検討を要する。次 に, 多発性硬化症のモデルである experimental autoimmune encephalomyelitis (EAE) では, 疾患 の誘導時に制御性 $T$ 細胞を除去すると, 脳脊䯣炎 の発症率や重症度が上昇する。また, 制御性 $\mathrm{T}$ 細 胞を発症前に移入することで，やはりその発症を予 防することができる11,12)、関節リウマチのモデルで あるコラーゲン誘発性関節炎でも, 疾患誘導時に制 御性 $\mathrm{T}$ 細胞を除去すると, その重症度が上が る ${ }^{13)}$ 。その際に, 制御性 $\mathrm{T}$ 細胞を移入すると, 予 防することはできないが, 重症度は低下する, 最後 に，全身性エリテマトーデス（SLE）のモデルマウ スである，MRL/MP マウスでは，制御性 $\mathrm{T}$ 細胞自 体には異常を認めないが, CD25-CD4+細胞が, 試験管内での制御性 $\mathrm{T}$ 細胞による抑制に対して耐 性である14)。このことは, 受動的な意味での制御性 $\mathrm{T}$ 細胞による抑制異常が発症に関与している可能性 を示している.

\section{4. 制御性 $\mathbf{T}$ 細胞とヒト自己免疫疾患}

前述したモデルマウスのみならず，実際，さまざ まな自己免疫疾患患者で, 制御性 $\mathrm{T}$ 細胞に異常を 認めるという報告が集積されている．I 型糖尿病患 者では，制御性 $\mathrm{T}$ 細胞の数は正常だが，その抑制 能が低下している15)。多発性硬化症患者でも, 制御 性 $\mathrm{T}$ 細胞の数は正常だが，その抑制能が低下して いる16).ただし, 両者ともに, 患者由来の制御性 T 細胞の抑制能に差がないという報告もある17,18)。い わゆる膠原病患者においても類似の異常は報告され ている，例えば，関節リウマチ患者では，炎症性サ イトカイン分泌に対する, 制御性 $\mathrm{T}$ 細胞の抑制能 が低下しており, 抗 TNF- $\alpha$ 抗体治療後, その抑制 能が回復する ${ }^{19)}$ 。また，リウマチ患者の関節液中の 制御性 $\mathrm{T}$ 細胞は, 活性化されており, その抑制能 
表 2 制御性 $\mathrm{T}$ 細胞の異常と自己免疫疾患

\begin{tabular}{|c|c|c|c|}
\hline \multicolumn{2}{|c|}{ ヒト自己免疫疾患 } & \multicolumn{2}{|c|}{ 自己免疫疾患モデルマウス } \\
\hline 関節リウマチ & CD25-T 細胞が而性 & CIA & 除去すると重症化 \\
\hline 全身性エリテマトーデス & 活動期に減少 & MRL & CD25-T 細胞が而性 \\
\hline 強皮症 & 不明 & TSK & 不明 \\
\hline 多発性筋炎 & 不明 & & \\
\hline シェーグレン症候群 & 異常なし & aly/aly & 減少？ \\
\hline ANCA 関連性血管炎 & 増加 & $\mathrm{SCG} / \mathrm{kj}$ & 不明 \\
\hline ベーチェット病 & 不明 & & \\
\hline 川崎病 & 減少 & & \\
\hline 混合性クリオグロブリン血症 & 減少 & & \\
\hline 多発性硬化症 & 機能不全 & EAE & 除去すると重症化 \\
\hline ギランバレー症候群 & 不明 & EAN & 不明 \\
\hline 筋無力症 & 機能不全 & & \\
\hline I 型糖尿病 & 減少/機能不全/異常なし & NOD & 加齢とともに機能低下 \\
\hline バセドウ病 & 不明 & & \\
\hline 橋本病 & 不明 & EAT & G-CSF 治療で増加 \\
\hline アジソン病 & 不明 & & \\
\hline IPEX & 欠損 & Scurfy & 欠損 \\
\hline APS type-II & 機能不全 & & \\
\hline 自己免疫性心筋炎 & 不明 & EAM & 不明 \\
\hline 間質性肺炎 & 不明 & & \\
\hline 気管支喘息 & 増悪時に増加 & & \\
\hline 自己免疫性肝炎 & 減少, 機能不全 & $\mathrm{EAH}$ & 不明 \\
\hline 原発性胆汁性肝硬変 & 不明 & & \\
\hline クローン病 & 不明 & SAMP1/yit & 機能不全? \\
\hline 潰瘍性大腸炎 & 不明 & & \\
\hline 乾癬 & 機能不全 & & \\
\hline アトピー性皮膚炎 & 増加, 機能不全? & & \\
\hline 溶血性貧血 & 不明 & murine AIHA & 除去すると発症率上昇 \\
\hline
\end{tabular}

が同じ患者の末梢血中の制御性 $\mathrm{T}$ 細胞よりも高い が，関節液中の CD4+CD25- T 細胞はその抑制に 耐性を示す20)。 また, 活動期の SLE 患者では, 非 活動期の患者や健常人に比べて, 制御性 $\mathrm{T}$ 細胞数 が減少している21)。一方，シェーグレン症候群の患 者では, 制御性 $\mathrm{T}$ 細胞数は増加しており, その機 能にも異常を認めない22). その他, 自己免疫性肝炎,

Autoimmune polyendocrinopathy syndrome (APS) type 2, 乾癬, 筋無力症, 川崎病, ANCA 関連性血 管炎などの患者でも，何らかの制御性 $\mathrm{T}$ 細胞の異 常が示されている23〜29). こういつた，ヒト自己免 疫疾患で制御性 $\mathrm{T}$ 細胞に異常があるかどうか検討
する際の問題点は, ヒトでは $\mathrm{CD} 25+\mathrm{T}$ 細胞に多く の非制御性 $\mathrm{T}$ 細胞が混在し, しかもその割合に個 人差が大きいことである。また，制御性 $\mathrm{T}$ 細胞に 異常を認める場合でも, 疾患の原因なのか, 炎症が 起きた結果なのかが, 判然としない.したがって, 現在のところ, 制御性 $\mathrm{T}$ 細胞の数的あるいは質的 異常が，全てのヒト自己免疫疾患の発症に関与して いるとは断定できないが，少なくとも，エフェク ター $\mathrm{T}$ 細胞による病的な自己反応と制御性 $\mathrm{T}$ 細胞 によるその抑制のバランスが，さまざまな自己免疫 疾患で崩れている. 

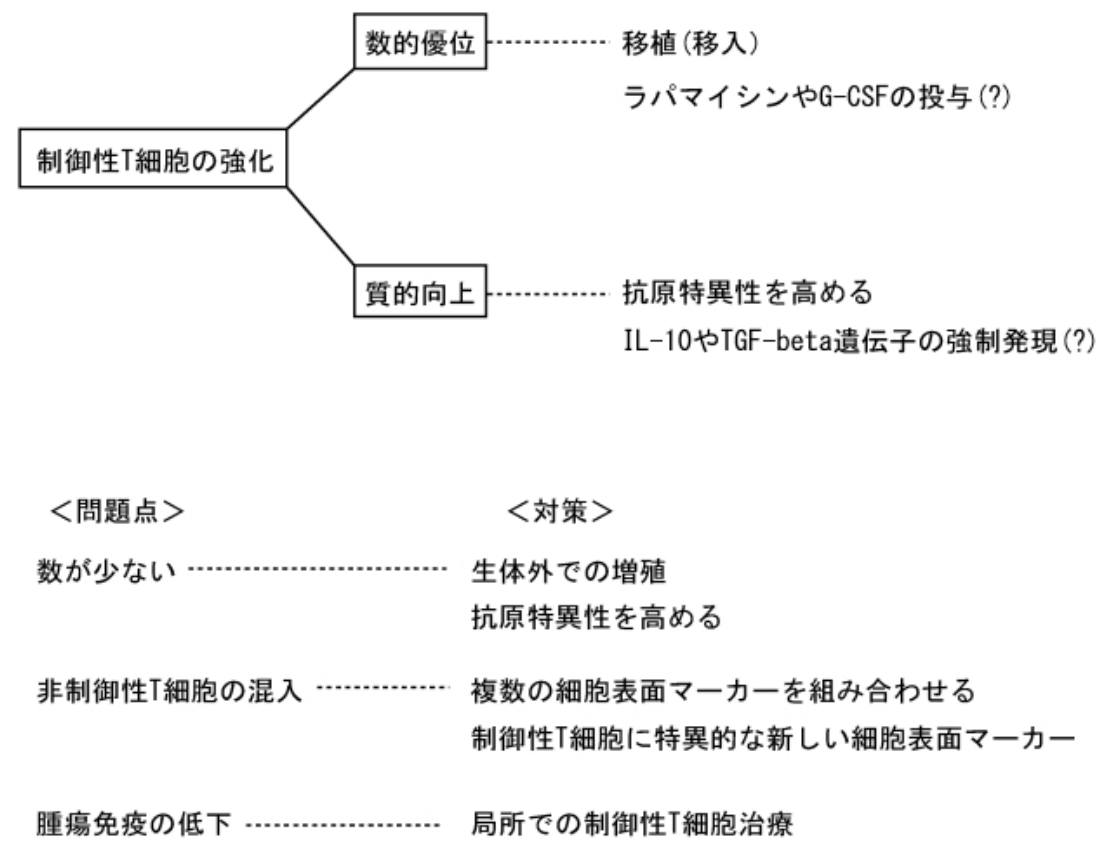

図 3 制御性 $\mathrm{T}$ 細胞を用いた自己免疫疾患の治療 その問題点と対策

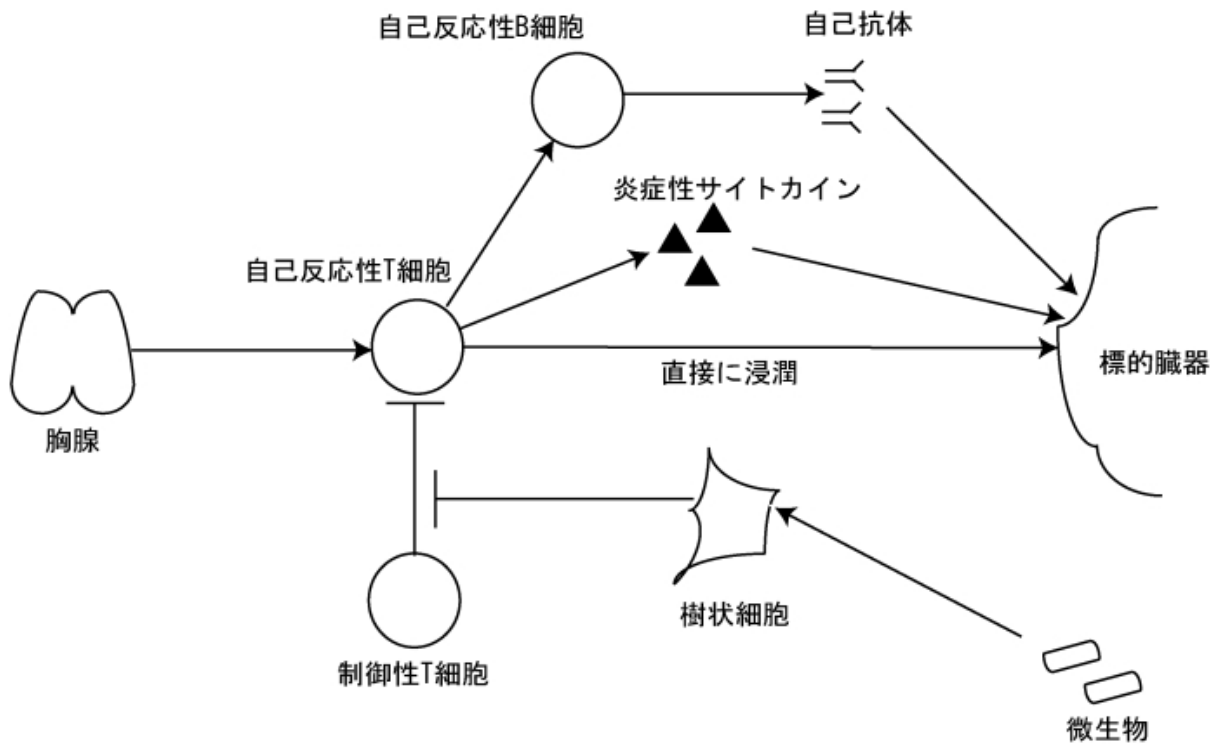

図 4 自己免疫の発症と制御性 $\mathrm{T}$ 細胞

\section{5. 制御性 $\mathbf{T}$ 細胞と自己抗体}

自己反応性 $\mathrm{T}$ 細胞とともに, 自己免疫の病態を 考えるうえで不可欠な要素が自己抗体であるが, 制 御性 $\mathrm{T}$ 細胞は，自己抗体産生をも抑制している. 前述したように, BALB/c CD25-CD4+ 細胞と制 御性 $\mathrm{T}$ 細胞を同系ヌードマウスに共移入すると, 自己免疫性胃炎の発症が抑制される。このとき, 自 己免疫性胃炎特異的な自己抗体である抗胃壁細胞抗 体の産生も抑制される. EAEにおいても同様に疾 患特異的な自己抗体の産生が，制御性 $\mathrm{T}$ 細胞によ
り抑制される。ただし，これらの疾患では，自己反 応性 $\mathrm{CD} 4+\mathrm{T}$ 細胞が, その病態の本体であり, 制 御性 $\mathrm{T}$ 細胞は, そのような自己反応性 $\mathrm{T}$ 細胞を抑 制することで，間接的に自己抗体産生を抑制してい ると思われる。一方, 膠原病特異的な自己抗体に関 しても，同様の報告がある，例えば，抗二重鎖 DNA 抗体を産生するような B 細胞は, $\mathrm{T}$ 細胞のへ ルプを受けて活性化するが, この際に制御性 T 細 胞が共存すると, その活性化が抑制され, 抗二重鎖 DNA 抗体は産生されない30,31)。したがって，この 場合も, 制御性 $\mathrm{T}$ 細胞が直接的に自己反応性 B 細 
胞を抑制するのではなく，そのような $\mathrm{B}$ 細胞をへ ルプする $\mathrm{T}$ 細胞を抑制するという間接的な機序が 働いている. SLEにおいて, 抗 DNA 抗体は病態形 成に重要であり, 制御性 $\mathrm{T}$ 細胞が間接的であるに せよ抗 DNA 抗体産生に関与していることは, SLE の病態解明や治療法開発に結びつく可能性がある.

\section{6. 制御性 $\mathbf{T}$ 細胞と innate immunity}

これまでに述べてきたことから，制御性 $\mathrm{T}$ 細胞 が自己免疫に抑制的に働き，その異常が自己免疫疾 患の発症に関与していることは明らかである。で は，制御性 $\mathrm{T}$ 細胞による末梢での免疫自己寛容が 破綻する機序はどうなっているのであろうか。一つ の可能性は, IPEX で認められるように, 先天的に 制御性 $\mathrm{T}$ 細胞が欠損あるいは機能異常をもってい る場合である。しかし，実際には，多くの自己免疫 疾患の発症は成人以降であり，一卵性双生児間の一 致も不完全であることから，遺伝的因子だけでな く, 環境因子が関与していると考えられる. 特に, 制御性 $\mathrm{T}$ 細胞と innate immunity の関係は重要であ る. 微生物が生体内に侵入すると, 抗原提示細胞, 主として樹状細胞が活性化するが，この際，制御性 $\mathrm{T}$ 細胞による抑制が解除される可能性がある32)。こ の作用には, Toll-like receptor を介して活性化され た樹状細胞によるインターロイキン-6 産生が関与 している.この機序は, 微生物に反応するエフェク ター $\mathrm{T}$ 細胞が抑制されないので, 感染症に対して は有利に作用する。しかし，もしその作用が遷延す ると, 自己反応性エフェクター細胞の活性化を許容 し，自己免疫の発症につながるかもしれない。これ を支持する知見として，マウスに抗 IL-2 抗体を投 与すると, 一過性に制御性 $\mathrm{T}$ 細胞が減少するが, その間に各種自己免疫疾患が生じ，それらは，制御 性 $\mathrm{T}$ 細胞数が回復しても治癒しないことがある. したがって, 自己免疫疾患の発症には, 制御性 T 細胞による抑制が，一定期間，解除されていればよ いと思われる. 多くのヒト自己免疫疾患において, 発症の契機に感染症を認める. 従来, 感染微生物と 交差する自己抗原の存在や, 微生物による抗原提示 細胞の活性化などが，その機序とされてきた。 しか し，上記のような，innate immunity の活性化によ る制御性 $\mathrm{T}$ 細胞の抑制解除も, 発症の契機となり うる. 詳細については, 今後のさらなる研究が必要 である.

\section{7. 制御性 $\mathbf{T}$ 細胞を用いた自己免疫病の治療}

制御性 $\mathrm{T}$ 細胞を移入することで, 免疫自己寛容 を強化し, 自己免疫疾患の治療を行う試みは, いく つもの自己免疫疾患モデルで検討されている．例え ば，腸炎モデルやEAE, NOD マウスでは，その疾 患の発症後に制御性 $\mathrm{T}$ 細胞を移入することで, 疾 患が治癒する33 35)。しかし，このような蔵器特異 的な自己免疫疾患に比べて, 関節リウマチモデルの コラーゲン誘導性関節炎に対しては, 制御性 $\mathrm{T}$ 細 胞移入の治療効果は小さい36). プロテオグリカン誘 導性関節炎でも, 制御性 $\mathrm{T}$ 細胞は関節炎を抑制で きない37)。このことは, 臟器特異的自己免疫疾患で は自己反応性 $\mathrm{T}$ 細胞が直接に標的臓器を破壊する のに対して, 自己免疫性関節炎では $\mathrm{T}$ 細胞がマク ロファージや滑膜細胞に作用して, 間接的に標的器 官を破壊するからかもしれない，あるいは，関節炎 では, IL-6 などの炎症性サイトカインの影響によ り制御性 $\mathrm{T}$ 細胞が作用しにくい環境にあるのかも しれない。一方，生体外から制御性 $\mathrm{T}$ 細胞を移入 するのでなく, 生体内で制御性 $\mathrm{T}$ 細胞を特異的に 増殖させる薬剤の探索も進んでいる. 免疫抑制剤の 一種であるラパマイシンは, 少なくとも生体外では 制御性 $\mathrm{T}$ 細胞を選択的に増殖させるため, 自己免 疫疾患の治療に際して, 他の免疫抑制剂よりも有利 に作用する可能性がある ${ }^{38,39)}$. また, G-CSF 投与 により, 制御性 $\mathrm{T}$ 細胞が自己免疫標的臓器に集積 しやすいことが報告されている40).また，これまで 述べてきたような, 制御性 $\mathrm{T}$ 細胞の量的な調節の アプローチだけでなく, 質的な調節を行うような薬 剤や抗体の探索も進んでいる. インターロイキンー 10 や TGF-beta は, 従来から, 炎症に対して抑制 的に作用するサイトカインとして知られているが, $\mathrm{CD} 25+\mathrm{CD} 4+$ 制御性 $\mathrm{T}$ 細胞による抑制にも関わつ ているかもしれない. アデノウイルスを用いて, こ れらのサイトカインを生体内で強制発現させると, NOD マウスでの糖尿病発症を抑制し, その際に $\mathrm{CD} 25+\mathrm{CD} 4+$ 制御性 $\mathrm{T}$ 細胞が関与していることが 示唆されている ${ }^{41,42)}$. 以上のように, 制御性 $\mathrm{T}$ 細 胞の抑制機能を直接的あるいは間接的に強化して, 自己免疫の治療を行うことが, マウスでは可能であ る.

\section{8. 制御性 $\mathbf{T}$ 細胞を用いたヒト自己免疫の治療}

マウスでの制御性 $\mathrm{T}$ 細胞による免疫疾患の治療 
を，ヒトへと応用する場合，いくつかの課題があ る. まず，制御性 $\mathrm{T}$ 細胞を移入するにあたつて， ドナーおよび移入細胞数を決定せねばならない。制 御性 $\mathrm{T}$ 細胞は，末梢 $\mathrm{CD} 4+\mathrm{T}$ 細胞の 5-10\%に過ぎ ないため, 一人のドナーより多くの細胞を採取する ことが困難である，MHC 適合を考慮すれば，自己 血由来の制御性 $\mathrm{T}$ 細胞を移入することが望ましい が, 同じ理由で難しい。 また，自己免疫疾患の治療 に際しては，一旦，活性化した $\mathrm{T}$ 細胞を抑制せね ばならず，予防するときよりも多くの制御性 $\mathrm{T}$ 細 胞を移入する必要がある。ささらに，マウスと異な り，ヒトでは， $\mathrm{CD} 25+\mathrm{CD} 4+\mathrm{T}$ 細胞中に，たくさ んの非制御性 $\mathrm{T}$ 細胞が含まれており, 単に CD25+ 細胞を移入すると, 同時に多くの活性化 $\mathrm{T}$ 細胞を 移入してしまう。また, 制御性 $\mathrm{T}$ 細胞は自己免疫 のみならず，腫瘍免疫をも抑制するため, 制御性 T 細胞移入により, 人によっては, 腫瘍発生のリスク が高まるかもしれない. 上記のような問題点に対し て，さまざまな工夫が試みられている，まず，制御 性 $\mathrm{T}$ 細胞を体外で増殖させて, その数が少ないこ とを補う方法がある43). またその際に，標的抗原を 提示させて, 制御性 $\mathrm{T}$ 細胞の抗原特異性を高める ことも可能である ${ }^{35)}$. さらには, 培養にサイトカイ ンを組み合わせて加えることにより, 非制御性 T 細胞から制御性 $\mathrm{T}$ 細胞を抗原特異的に作り出せる との報告もある ${ }^{44,45)}$. 一方, $\mathrm{CD} 25+$ 活性化 $\mathrm{T}$ 細胞 の混入に対しては, 制御性 $\mathrm{T}$ 細胞に, より特異的 な細胞表面マーカーが必要である. 現在のところ, 制御性 T 細胞に最も特異的な分子は FoxP3 である が，これは細胞表面に発現していないため，制御性 生きた $\mathrm{T}$ 細胞の採取には不向きである。いくつか の細胞表面抗原を組み合わせて, より純度の高い制 御性 $\mathrm{T}$ 細胞を採取することは可能であるが, 制御 性 $\mathrm{T}$ 細胞に対する, 簡便で特異度の高いマーカー が期待される.

\section{9. を め}

制御性 $\mathrm{T}$ 細胞は, 自己反応性 $\mathrm{T}$ 細胞を抑制し, 末梢での免疫自己寛容の維持に重要な働きをしてい る. 制御性 $\mathrm{T}$ 細胞の異常は, 自己免疫が起きる原 因の全てではないが, 自己免疫疾患全般の発症に大 きく関与している.この細胞を用いて, 免疫疾患の 治療を行うことは生理的であり, 理にかなっている が, 臨床応用するには, 解決すべき課題は多い。制 御性 $\mathrm{T}$ 細胞による抑制機序を解明し，このユニー
クな細胞をコントロールできるようになれば，自己 免疫疾患の原因究明と治療に寄与するであろう.

\section{文献}

1) Sakaguchi S. : Naturally arising CD4+ regulatory cells for immunologic self-tolerance and negative control of immune responses. Arru Rev Immunol 22 : 531-562, 2004.

2) Hori $S$, Nomura $T$, Sakaguchi S. : Control of regulatory $\mathrm{T}$ cell development by the transcription factor Foxp3. Science 299: 1057-1061, 2003.

3) Hsieh CS, Liang Y, Tyznik AJ, Self SG, Liggitt D, Rudensky AY. : Recognition of the peripheral self by naturally arising $\mathrm{CD} 25+$ CD4 + T cell receptors. Immunity $21: 267-277$, 2004.

4) Setoguchi R, Hori S, Takahashi $T$, Sakaguchi S. : IL-2 and autoimmunity: homeostatic maintenance of $\mathrm{CD} 25+\mathrm{CD} 4+$ regulatory $\mathrm{T}$ cells via $\mathrm{IL}-2$ secreted by other $\mathrm{T}$ cells and induction of autoimmune disease by $\mathrm{IL}-2$ neutralization. J Exp Med. 2005.

5) Sakaguchi $S$, Sakaguchi $N$, Asano $M$, Itoh $M$, Toda M. : Immunologic self[-tolerance maintained by activated $T$ cells expressing IL-2 receptor alpha-chains (CD25). Breakdown of a single mechanism of self-tolerance causes various autoimmune diseases. J Immunol 155 : 1151-1164, 1995.

6) Asano M, Toda M, Sakaguchi N, Sakaguchi S. : Autoimmune disease as a consequence of developmental abnormality of a $\mathrm{T}$ cell subpopulation. J Exp Med 184 : 387-96, 1996.

7) Brunkow ME, Jeffery EW, Hjerrild KA, et al. : Disruption of a new forkhead/winged-helix protein, scurfin, results in the fatal lymphoproliferative disorder of the scurfy mouse. Nat Genet $27: 68-73 ; 2001$.

8) Bennett CL, Christie J, Ramsdell F, et al. : The immune dysregulation, polyendocrinopathy, enteropathy, X-linked syndrome (IPEX) is caused by mutations of FOXP3. Nat Genet 27 : 20-21, 2001.

9) $\mathrm{Wu}$ AJ, Hua H, Munson SH, McDevitt HO.: Tumor necrosis factor-alpha regulation of $\mathrm{CD} 4+\mathrm{CD} 25+\mathrm{T}$ cell levels in NOD mice. Proc Natl Acad Sci U S A 99 : 12287-12292, 2002.

10) Gregori $S$, Giarratana $N$, Smiroldo S, Adorini L. : Dynamics of pathogenic and suppressor $\mathrm{T}$ 
cells in autoimmune diabetes development. $J$ Immunol 171 : 4040-4047, 2003.

11) Kohm AP, Carpentier PA, Anger HA, Miller SD. : Cutting edge : CD4 + CD25+ regulatory $\mathrm{T}$ cells suppress antigen-specific autoreactive immune responses and central nervous system inflammation during active experimental autoimmune encephalomyelitis. J Immunol 169 : 4712-4716, 2002.

12) Hori S, Haury M, Coutinho A, Demengeot J. : Specificity requirements for selection and effector functions of $\mathrm{CD} 25+4+$ regulatory $\mathrm{T}$ cells in anti-myelin basic protein $\mathrm{T}$ cell receptor transgenic mice. Proc Natl Acad Sci U S A 99 : 8213-8218, 2002.

13) Morgan ME, Sutmuller RP, Witteveen $\mathrm{HJ}$, et al. : CD25 + cell depletion hastens the onset of severe disease in collagen-induced arthritis. Arthritis Rheum 48 : 1452-1460, 2003.

14) Monk CR, Spachidou M, Rovis F, et al. : MRL /Mp CD4+, CD25 - $\mathrm{T}$ cells show reduced sensitivity to suppression by $\mathrm{CD} 4+, \mathrm{CD} 25+$ regulatory $\mathrm{T}$ cells in vitro : a novel defect of $\mathrm{T}$ cell regulation in systemic lupus erythematosus. Arthritis Rheum 52 : 1180-1184, 2005.

15) Lindley S, Dayan CM, Bishop A, Roep BO, Peakman M, Tree TI. : Defective suppressor function in $\mathrm{CD} 4(+) \mathrm{CD} 25(+) \mathrm{T}$-cells from patients with type 1 diabetes. Diabetes 54 : 9299, 2005.

16) Viglietta $\mathrm{V}$, Baecher-Allan $\mathrm{C}$, Weiner HL, Hafler DA. : Loss of functional suppression by $\mathrm{CD} 4+\mathrm{CD} 25+$ regulatory $\mathrm{T}$ cells in patients with multiple sclerosis. J Exp Med 199 : 971979, 2004.

17) Putnam AL, Vendrame F, Dotta F, Gottlieb PA. : $\mathrm{CD} 4+\mathrm{CD} 25$ high regulatory $\mathrm{T}$ cells in human autoimmune diabetes. J Autoimmun $24:$ 55-62, 2005.

18) Putheti P, Pettersson A, Soderstrom M, Link H, Huang YM. : Circulating CD4 $+\mathrm{CD} 25+\mathrm{T}$ regulatory cells are not altered in multiple sclerosis and unaffected by disease-modulating drugs. J Clin Immunol 24 : 155-161, 2004.

19) Ehrenstein MR, Evans JG, Singh A, et al. : Compromised function of regulatory $\mathrm{T}$ cells in rheumatoid arthritis and reversal by antiTNFalpha therapy. J Exp Med $200: 277-285$, 2004.

20) van Amelsfort JM, Jacobs KM, Bijlsma JW, Lafeber FP, Taams LS. : CD4(+)CD25(+) regulatory $\mathrm{T}$ cells in rheumatoid arthritis : differences in the presence, phenotype, and function between peripheral blood and synovial fluid. Arthritis Rheum 50 : 2775-2785, 2004.

21) Crispin JC, Martinez A, Alcocer-Varela J. Quantification of regulatory $\mathrm{T}$ cells in patients with systemic lupus erythematosus. J Autoimmun 21 : 273-276, 2003.

22) Gottenberg JE, Lavie F, Abbed K, et al. : CD4 $\mathrm{CD} 25$ high regulatory $\mathrm{T}$ cells are not impaired in patients with primary Sjogren's syndrome. $J$ Autoimmun 24 : 235-242, 2005.

23) Sugiyama H, Gyulai R, Toichi E, et al. : Dysfunctional blood and target tissue CD4+CD25 high regulatory $\mathrm{T}$ cells in psoriasis : mechanism underlying unrestrained pathogenic effector $\mathrm{T}$ cell proliferation. $J$ Immunol $174: 164-$ $173,2005$.

24) Luther C, Poeschel S, Varga M, Melms A, Tolosa E. : Decreased frequency of intrathymic regulatory $\mathrm{T}$ cells in patients with myastheniaassociated thymoma. J Neuroimmunol 164 : 124-128, 2005.

25) Furuno K, Yuge T, Kusuhara K, et al. : CD25+ $\mathrm{CD} 4+$ regulatory $\mathrm{T}$ cells in patients with Kawasaki disease. J Pediatr $145:$ 385-390, 2004.

26) Kriegel MA, Lohmann $T$, Gabler C, Blank N, Kalden JR, Lorenz HM. : Defective suppressor function of human $\mathrm{CD} 4+\mathrm{CD} 25+$ regulatory $\mathrm{T}$ cells in autoimmune polyglandular syndrome type II. J Exp Med 199 : 1285-1291, 2004.

27) Longhi MS, Ma Y, Bogdanos DP, Cheeseman P, Mieli-Vergani G, Vergani D. : Impairment of $\mathrm{CD} 4(+) \mathrm{CD} 25(+)$ regulatory $\mathrm{T}$-cells in autoimmune liver disease. $J$ Hepatol 41 : 31-37, 2004.

28) Balandina A, Lecart S, Dartevelle P, Saoudi A, Berrih-Aknin S. : Functional defect of regulatory CD4 $(+) \mathrm{CD} 25+\mathrm{T}$ cells in the thymus of patients with autoimmune myasthenia gravis. Blood 105 : 735-741, 2005.

29) Marinaki S, Neumann I, Kalsch AI, et al. : Abnormalities of CD4 $\mathrm{T}$ cell subpopulations in ANCA-associated vasculitis. Clin Exp Immunol 140 : 181-191, 2005.

30) Seo SJ, Fields ML, Buckler JL, et al. : The impact of $T$ helper and $T$ regulatory cells on the regulation of anti-double-stranded DNA B cells. Immunity 16 : 535-546, 2002.

31) La Cava A, Ebling FM, Hahn BH. : Ig-reactive 
$\mathrm{CD} 4+\mathrm{CD} 25+\mathrm{T}$ cells from tolerized (New Zealand Black $\times$ New Zealand White) F1 mice suppress in vitro production of antibodies to DNA. J Immunol 173 : 3542-3548, 2004.

32) Pasare C, Medzhitov R. : Toll pathway-dependent blockade of CD4 $+\mathrm{CD} 25+\mathrm{T}$ cell-mediated suppression by dendritic cells. Science 299 : 1033-1036, 2003.

33) Mottet C, Uhlig HH, Powrie F. : Cutting edge : cure of colitis by $\mathrm{CD} 4+\mathrm{CD} 25+$ regulatory $\mathrm{T}$ cells. J Immunol 170 : 3939-3943, 2003.

34) Mekala DJ, Geiger TL. : Immunotherapy of autoimmune encephalomyelitis with re-directed CD4+CD25 + T-lymphocytes. Blood 2004.

35) Tang Q, Henriksen KJ, Bi M, et al. : In vitroexpanded antigen-specific regulatory $\mathrm{T}$ cells suppress autoimmune diabetes. J Exp Med 199 : 1455-1465, 2004.

36) Morgan ME, Flierman $R$, van Duivenvoorde LM, et al. : Effective treatment of collagen-induced arthritis by adoptive transfer of CD25+ regulatory T cells. Arthritis Rheum $52: 2212-$ 2221, 2005.

37) Bardos $T$, Czipri M, Vermes $C$, Finnegan A, Mikecz K, Zhang J. : CD4+CD25+ immunoregulatory $\mathrm{T}$ cells may not be involved in controlling autoimmune arthritis. Arthritis Res Ther 5 : R106-R113, 2003.

38) Baan CC, van der Mast BJ, Klepper M, et al. : Differential effect of calcineurin inhibitors, anti-CD25 antibodies and rapamycin on the induction of FOXP3 in human T cells. Transplantation 80 : 110-117, 2005.

39) Battaglia M, Stabilini A, Roncarolo MG. : Rapamycin selectively expands CD4+CD25+
FoxP3 + regulatory T cells. Blood $105: 4743-$ 4748, 2005.

40) Hadaya K, Kared H, Masson A, Chatenoud L, Zavala F. : G-CSF treatment prevents cyclophosphamide acceleration of autoimmune diabetes in the NOD mouse. J Autoimmun 24 : 125-134, 2005.

41) Goudy KS, Burkhardt BR, Wasserfall C, et al. : Systemic overexpression of IL-10 induces CD4 $+\mathrm{CD} 25+$ cell populations in vivo and ameliorates type 1 diabetes in nonobese diabetic mice in a dose-dependent fashion. $J$ Immunol 171 : 2270-2278, 2003.

42) Luo X, Yang H, Kim IS, et al. : Systemic transforming growth factor-betal gene therapy induces Foxp $3+$ regulatory cells, restores selftolerance, and facilitates regeneration of beta cell function in overtly diabetic nonobese diabetic mice. Transplantation 79: 1091-1096, 2005.

43) Taylor PA, Lees CJ, Blazar BR. : The infusion of ex vivo activated and expanded CD4 $(+)$ CD25(+) immune regulatory cells inhibits graft-versus-host disease lethality. Blood 99 : 3493-3499, 2002.

44) Chen W, Jin W, Hardegen N, et al. : Conversion of peripheral $\mathrm{CD} 4+\mathrm{CD} 25-$ naive $\mathrm{T}$ cells to $\mathrm{CD} 4+\mathrm{CD} 25+$ regulatory $\mathrm{T}$ cells by TGFbeta induction of transcription factor Foxp3. $J$ Exp Med 198 : 1875-1886, 2003.

45) Zheng SG, Gray JD, Ohtsuka K, Yamagiwa S, Horwitz DA. : Generation ex vivo of TGFbeta-producing regulatory $\mathrm{T}$ cells from $\mathrm{CD} 4+$ CD25 - precursors. J Immunol 169:41834189, 2002. 